\title{
Fungal remains from late Neogene deposits at the Gray Fossil Site, Tennessee, USA
}

\author{
Worobiec $\mathrm{G}^{1}$, Worobiec $\mathrm{E}^{1}$ and Liu $\mathrm{YC}^{2}$
}

\author{
${ }^{1}$ W. Szafer Institute of Botany, Polish Academy of Sciences, Lubicz 46, PL-31-512 Kraków, Poland \\ ${ }^{2}$ Department of Biological Sciences and Office of Research \& Sponsored Projects, California State University, \\ Fullerton, CA 92831, U.S.A.
}

Worobiec G, Worobiec E, Liu YC 2018 - Fungal remains from late Neogene deposits at the Gray Fossil Site, Tennessee, USA. Mycosphere 9(5), 1014-1024, Doi 10.5943/mycosphere/9/5/5

\begin{abstract}
Interesting fungal remains were encountered during palynological investigation of the Neogene deposits at the Gray Fossil Site, Washington County, Tennessee, USA. Both Cephalothecoidomyces neogenicus and Trichothyrites cf. padappakarensis are new for the Neogene of North America, while remains of cephalothecoid fungus Cephalothecoidomyces neogenicus G. Worobiec, Neumann \& E. Worobiec, fragments of mantle tissue of mycorrhizal Cenococcum and sporocarp of epiphyllous Trichothyrites cf. padappakarensis (Jain \& Gupta) Kalgutkar \& Jansonius were reported. Remains of mantle tissue of Cenococcum for the fossil state are reported for the first time. The presence of Cephalothecoidomyces, Trichothyrites, and other fungal remains previously reported from the Gray Fossil Site suggest warm and humid palaeoclimatic conditions in the southeast USA during the late Neogene, which is in accordance with data previously obtained from other palaeontological analyses at the Gray Fossil Site.
\end{abstract}

Key words - Cephalothecoid fungus - Epiphyllous fungus - Miocene/Pliocene - Mycorrhizal fungus - North America - palaeoecology - taxonomy

\section{Introduction}

Fungal organic remains, usually fungal spores and dispersed sporocarps, are frequently found in a routine palynological investigation (Elsik 1996). It is believed that these diverse fungal remains are often important as a palaeoecological proxy (Dilcher 1965, Lange 1976, Elsik 1978, Conran et al. 2016, Worobiec \& Worobiec 2017) and for calibration in refining the divergence time estimations in the phylogenetic trees obtained using molecular clock methods (Beimforde et al. 2014, Hongsanan et al. 2016, 2017, Liu et al. 2016, 2017, Mapook et al. 2016, Phukhamsakda et al. 2016, Samarakoon et al. 2016a, b, Sánchez-Ramírez et al. 2017). Considering these potential implications, we conducted a detailed investigation on diverse fungal remains found at the Gray Fossil Site located in Washington County, Tennessee, USA ( $\left.36^{\circ} 23^{\prime} 9.6^{\prime \prime} \mathrm{N}, 8^{\circ} 29^{\prime} 52.8^{\prime \prime} \mathrm{W}\right)$. Gray Fossil Site deposits of lacustrine origin covers an area of approximately $26,000 \mathrm{~m}^{2}$ (Shunk et al. 2006). The site, initially interpreted as the fills of a palaeosinkhole within the Cambro-Ordovician Knox Group (Shunk et al. 2006), is now suggested to be a multiple sinkholes/sub-basins that could represent asynchronous events (Zobaa et al. 2011, Worobiec et al. 2013). In the organic-rich, laminated sediments are preserved a variety of abundant fossils of both animals and plants (e.g. Liu \& Jacques 2010, Zobaa et al. 2011, Mead et al. 2012, Ochoa et al. 2012, 2016, Worobiec et al. 
2013, Huang et al. 2014, 2015), providing a critical insight into the palaeoecology and palaeoclimate conditions in the southeast USA during the late Neogene. The animal remains at Gray Fossil Site are diverse and abundant, exemplified by bones and teeth of alligators, anurans, badgers, bats, birds, lizards, red pandas, salamanders, snakes, tapirs, turtles, wolverines, among others (Parmalee et al. 2002, Wallace \& Wang 2004, Schubert \& Wallace 2006, Hulbert et al. 2009, Boardman \& Schubert 2011, Mead et al. 2012, Czaplewski 2017, Samuels et al. 2018), whereas the Neogene plant communities at Gray Fossil Site represent open woodlands with oaks and hickories, mixed with diverse vines and shrubs existing in a warm temperate to subtropical climate (Gong et al. 2010, Liu \& Jacques 2010, Ochoa et al. 2012, Worobiec et al. 2013). On the basis of the presence of Teleoceras and Plionarctos, Gray Fossil Site deposits have been dated to a range from 7.0 to $4.5 \mathrm{Ma}$, i.e. the latest Miocene to earliest Pliocene (Wallace \& Wang 2004, Shunk et al. 2006). Among the investigated fossils from Gray Fossil Site, however, fossil fungal remains were interestingly not studied in detail, although Zobaa et al. (2011) found remains of sporocarps of Callimothallus sp., Ochoa et al. (2012) reported a presence of fungal remains in pollen profiles (with no details) and Worobiec et al. (2013) noted the occurrence of epiphyllous fungi (Microthyriales). In our recent palynological investigation of samples collected from four test-pits within Gray Fossil Site (Worobiec et al. 2013), various fungal remains representing forms that have not previously been reported from any Neogene deposits in North America were encountered. The present investigation aims at the taxonomy and palaeoecology of three different types of these fungi, viz. isolated plates of cephalothecoid peridium, fragments of mantle tissue, and sporocarp, from the Gray Fossil Site.

\section{Materials \& Methods}

In the previous palynological studies (Worobiec et al. 2013) a total of 15 samples were collected from four test-pits (Bear Pit, Elephant Pit, Test Pit 2-2010, and Rhino Pit) at the Gray Fossil Site. All samples were taken from the fossiliferous laminated facies. In the current investigation, all slides from the Bear Pit (four samples), Elephant Pit (four samples), and Test Pit 2-2010 (four samples) that contain higher frequencies of fungal remains were re-examined. Depending on the abundance of palynomorphs, 4 to 8 slides from each sample were examined in detail. Samples for palynomorph analysis were prepared by means of a modification of Erdtman's acetolysis method, using HF to remove the mineral matter (Moore et al. 1991), and were rinsed in a $5 \mu \mathrm{m}$ filter cloth. The microscope slides were made, using glycerine jelly as a mounting medium and cover-slips $24 \times 24 \mathrm{~mm}$. The rock samples, palynological residues, and slides are stored in the W. Szafer Institute of Botany, Polish Academy of Sciences, Kraków, Poland (Worobiec et al. 2013).

Terminology for the morphology of fungal remains (sporocarps and mantle tissue) follows Korf (1958), Ingleby et al. (1990), Wu et al. (2011). The method of measuring the size of fungal structures depends on their shape; and we used diameter measurements for regular, round or broadly elliptical structures, and length and width for quadrangular structures.

Bright field microphotography of the fossils was done using a NIKON Eclipse E400 microscope fitted with a CANON A640 digital camera.

\section{Results}

The classification of fossil and recent fungi follows Kalgutkar \& Jansonius (2000), Wu et al. (2011), Hongsanan \& Hyde (2017), Wijayawardene et al. (2018).

\section{Fungi incertae sedis}

Cephalothecoidomyces G. Worobiec, Neumann \& E. Worobiec, Fungal Biology 121: 287 (2017)

Cephalothecoidomyces neogenicus G. Worobiec, Neumann \& E. Worobiec, Fungal Biology 121: 287 (2017)

Fig. $1 \mathrm{a}-\mathrm{b}$ 
Three isolated plates of cephalothecoid ascoma, polygonal, 62-90 $\mu \mathrm{m}$ in size, composed of radiated cells (textura prismatica). Cells measuring ca. 4-6 $\mu \mathrm{m}$ long and 4-6 $\mu \mathrm{m}$ wide, dark and thick-walled.

Material examined - USA, Tennessee, Gray Fossil Site, spring 2010, D. Ochoa. Bear Pit, slides 2(1), 2(2), and Elephant Pit, slide 10(6). Three specimens.

Notes - Shape and structure of the above described fungal remains are closely comparable to the isolated plates of Cephalothecoidomyces neogenicus described from Neogene deposits of Germany and Poland (Worobiec et al. 2017). The eminent difference between them is in the dimension of cells in that the European material is 6-14 $\mu \mathrm{m}$ long, while Gray Fossil Site one is only 4-6 $\mu \mathrm{m}$ long. Remains of Cephalothecoidomyces represent peculiar type of fungal sporocarps that disaggregate into plates along lines of dehiscence. They are termed cephalothecoid ascomata (Greif et al. 2004, 2009, Kirk et al. 2008). Cephalothecoid ascomata varies ranging from peridia composed of large, complex plates (e.g. Cephalotheca) to small, simple plates as in the extant genus Chaetomidium (Greif et al. 2009). Cephalothecoidomyces neogenicus is probably related to the extant members of family Cephalothecaceae Höhn. that comprise four genera, such as Albertiniella Kirschst., Cephalotheca Fuckel, Cryptendoxyla Malloch \& Cain, and Phialemonium W. Gams \& McGinnis (Lumbsch \& Huhndorf 2010, Wijayawardene et al. 2012, Maharachchikumbura et al. 2016, Wijayawardene et al. 2018). From these genera, Cephalothecoidomyces neogenicus in respect of shape and arrangement of cells of peridial plates is most similar to the extant species of Cephalotheca and Cryptendoxyla (Worobiec et al. 2017).

Occurrence - Up to now Cephalothecoidomyces neogenicus is known only from two Neogene localities in Europe, viz. Adendorf, Gremany and Mizerna-Nowa, Poland (Worobiec et al. 2017). Fossil remains to some degree resembling genus Cephalothecoidomyces were reported as other fossil-taxa from Oligocene to Holocene deposits (see Worobiec et al. 2017).

\section{Ascomycota}

Gloniaceae (Corda) Boehm, Schoch \& Spatafora, Mycological Research 113 (4): 468 (2009)

Cenococcum Moug. \& Fr., Systema Mycologicum 3: 65 (1829)

Cenococcum cf. geophilum Fr., Systema Mycologicum 3: 66 (1829)

Fig. 1c-e

Several fragments of mantle tissue, up to ca. $200 \mu \mathrm{m}$ in size, composed of more or less rectangular cells (textura prismatica). Net synenchyma plectenchymatous, cells with thick walls, up to $17 \mu \mathrm{m}$ long, and 7.5-10 $\mu \mathrm{m}$ wide. Cells arranged in more or less regular stellate aggregations.

Material examined - USA, Tennessee, Gray Fossil Site, spring 2010, D. Ochoa. Bear Pit, slides 7(3), 19(2), 19(3), 19(4), and Elephant Pit, slides 10(2), 10(3). Thirteen specimens.

Notes - Cellular structure of the above described fungal remains, namely stellate arrangement of cells, is rather characteristic of mantle tissue (synenchyma), of one of the most frequently found extant mycorrhizal fungus Cenococcum geophilum Fr. (Ingleby et al. 1990, Agerer 1999, LoBuglio 1999, Agerer 2006). Somewhat similar structure of mantle tissue occurs in some extant species of genus Tomentella Pers. ex Pat. (Basidiomycota) (Jakucs \& Erös-Honti 2008). However, the cell arrangement in Tomentella is different from that in Cenococcum (see Jakucs \& Erös-Honti 2008, Fig. 1g). LoBuglio (1999) considered the characteristic cell arrangement of mantle tissue of Cenococcum as "stellate or cephalothecoid". Moreover, the cephalothecoid arrangement of cells of peridium is typical for the genus Elaphomyces Nees, which is considered as the sexual stage (teleomorph) of Cenococcum geophilum (LoBuglio et al. 1996). The cephalothecoid structure of fungal peridia is found in many extant often unrelated fungal genera (Worobiec et al. 2017), and rather similar cephalothecoid peridial wall structure to mantle tissue of Cenococcum geophilum could be found in some species of Chaetomidium (Zopf) Saccardo (Greif et al. 2009), rarely also from the genus Chaetomium Kunze (Doveri 2011, 2013, 2014). Rather similar cephalothecoid peridium to the mantle tissue of Cenococcum geophilum Fr. has fossil-species Adendorfia miocenica G. Worobiec, Neumann \& E. Worobiec, described from Miocene locality of Adendorf, Germany (Worobiec et al. 2017). Taking this into account, we reconsidered the determination of 
remains of Adendorfia miocenica and found that some of these remains with strongly elongated cells could in fact represent the mantle tissue of Cenococcum. On the other hand, remains of Adendorfia miocenica from Germany were accompanied by numerous fragments of trichomes similar to that covering the peridia of extant genera Chaetomidium and Chaetomium. In some cases, these trichomes were also preserved attached to small fragments of the peridium from Adendorf, Germany. Chaetomidium and Chaetomium are considered to be closely related to Adendorfia (Worobiec et al. 2017). As trichomes of this type were completely absent in the Gray Fossil Site, the presence of Adendorfia should be excluded and further discussed if these fungal remains seem to really represent the mantle tissue of Cenococcum geophilum. Presence in the fossil state of mantle tissue of Cenococcum is related to its resistance to the decomposition (Bird \& McCleneghan 2005). Nevertheless, as the deposits of the Gray Fossil Site lie rather shallow beneath the recent soil layer, it could not be excluded that remains of Cenococcum geophilum could be remnants of subfossil or even recent mycorrhizas from roots penetrating the soils. Kołaczek et al. (2013) pointed to possible contamination of mire deposits with spores of mycorrhizal fungi by roots penetrating the peat and discussed resulting problems with the interpretation of diagrams of non-pollen palynomorphs including spores of mycorrhizal fungi. On the other hand, the state of preservation, similar in all studied fungal remains, points rather to fossil origin of the studied Cenococcum remains.

Occurrence - To date remains of mantle tissue of Cenococcum have not been reported from the fossil state. Mudie \& Lelièvre (2013) reported "fragment of seriate fungal fruit body" from late Holocene deposits of Maligomisch, Nova Scotia, Canada that probably represents the fragment of mantle tissue of Cenococcum. Fossil sclerotia of Cenococcum, sometimes in high quantities, were reported from numerous localities of Pliocene to Quaternary age, particularly from archaeological sites (Shay \& Kapinga 1998, Bennike et al. 2002, Fischer \& Butzmann 2006). From the early Eocene amber of the Tadkeshwar Lignite Mine, Gujarat, India, Beimforde et al. (2011) described fragments of ectomycorrhizas of Eomelanomyces cenococcoides Beimforde, Dörfelt \& A. R. Schmidt. These authors considered preserved hyphae with iris diaphragms at the septa that extend outward from mantle as similar to the recent genus Cenococcum. However, in the opinion of Beimforde et al. (op. cit.), Eomelanomyces cenococcoides differs from Cenococcum in the high variability in the branching of the ectomycorrhizal systems and by the regular formation of microsclerotia. It should be added that preserved fragments of Eomelanomyces cenococcoides show no characteristic for Cenococcum stellate arrangement of cells of mantle tissue.

Microthyriaceae Sacc., Sylloge Fungorum 2: 658 (1883) vel Trichothyriaceae Theiss., Beihefte zum Botanischen Centralblatt 32: 3 (1914)

Trichothyrites Rosend. emend. Smith, Palaeontology, 23(1): 209 (1980) Synonyms:

Notothyrites Cookson, Proceedings of the Linnean Society of New South Wales 72: 208

Sphaerialites Venkatach. \& R.K. Kar, Palaeobotanist 17: 181 (1969)

Trichothyrites cf. padappakarensis (Jain \& Gupta) Kalgutkar \& Jansonius, American Association of Stratigraphic Palynologist Foundation Contributions Series 39: 303-304 (2000) Fig. 1f-i

One whole sporocarp and two fragments of other sporocarps, 63-127 $\mu \mathrm{m}$ in diameter. Scutellum composed of radiating rows of quadrilateral (textura prismatica) nonporate cells, up to 7 $\mu \mathrm{m}$ long and 2.5-5.0 $\mu \mathrm{m}$ wide. Radial cell walls usually straight, tangential cell walls usually rounded. In one specimen [Bear Pit 7(6)] are preserved both upper and lower wall of scutellum, their cells have more or less the same shape and dimensions. Ostiole central, roundish, 12.5-20.0 $\mu \mathrm{m}$ in diameter. Collar distinct, composed of three rows of small, isodiametric cells, with very thick and dark walls, ca. 3-4 $\mu \mathrm{m}$ in diameter.

Material examined - USA, Tennessee, Gray Fossil Site, spring 2010, D. Ochoa. Bear Pit, slide 7(6), Elephant Pit, slide 3(3), and Test Pit 2-2010, slide 2(5). Three specimens. 
Notes - Sporocarps with diameter exceeding $100 \mu \mathrm{m}$, structure of collar and scutellum cell size and arrangement are rather similar to the fossil-species Trichothyrites padappakarensis described from upper Miocene deposits of Padappakkara, Western Ghats, South India (Jain \& Gupta 1970). However, differences among the discussed three specimens from the Gray Fossil Site prevent unequivocal assignment of these fungal remains to Trichothyrites padappakarensis. Similar sporocarps (ascocarps) with roundish, central ostiole are usually found among extant members of the families Microthyriaceae and Trichothyriaceae (Wu et al. 2011, Hongsanan \& Hyde 2017). Among the recent representatives of Trichothyriaceae, two species of genus Lichenopeltella Höhn., L. pinophylla (Höhn.) P.M. Kirk \& Minter and L. nigroannulata (J. Webster) P.M. Kirk \& Minter, are the most similar to $T$. cf. padappakarensis from the Gray Fossil locality. The state of preservation of Trichothyrites remains from Gray Fossil Site (e.g. absence of asci and ascospores) prevents from detailed comparison with mentioned recent species of Lichenopeltella.
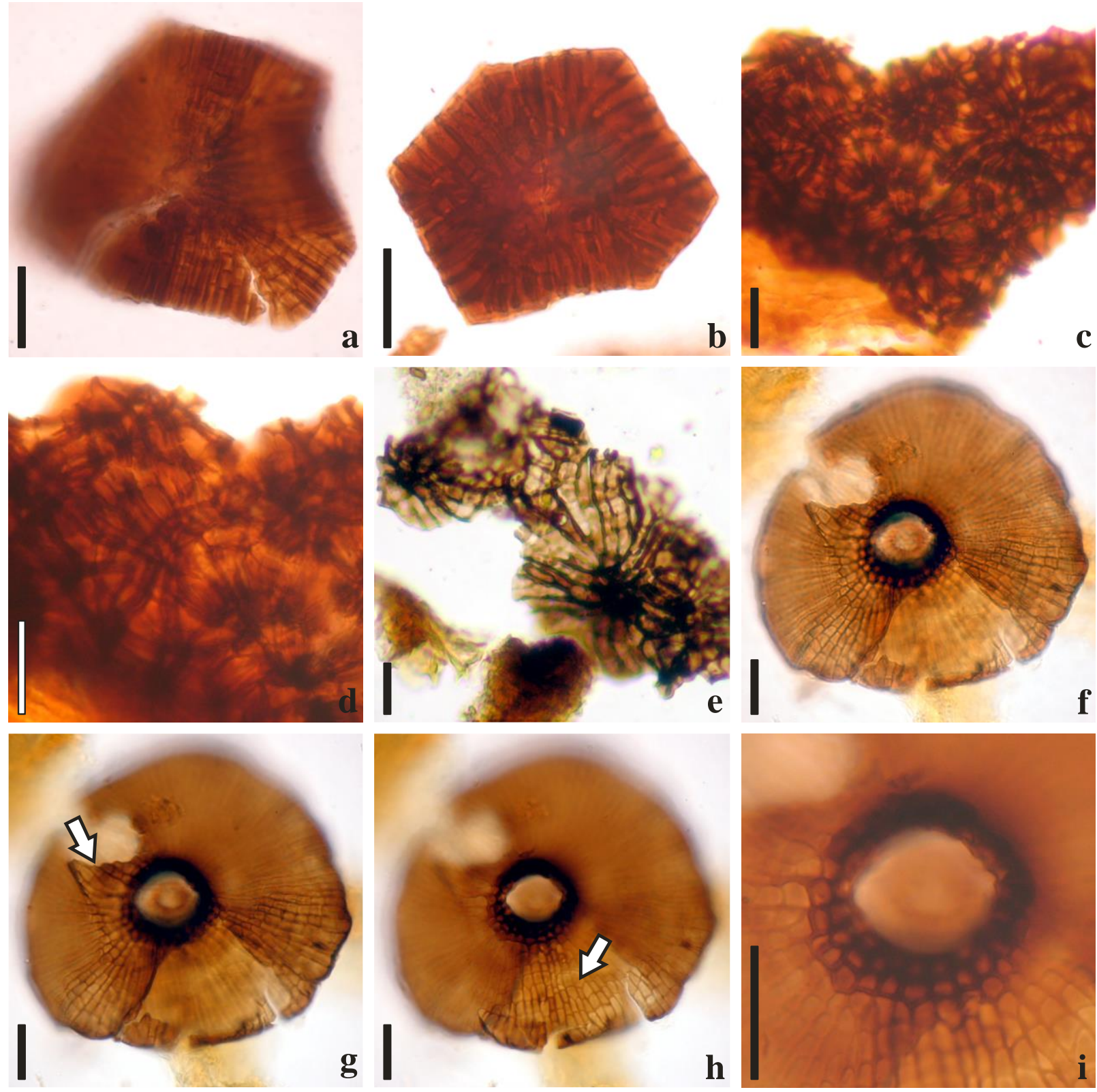

Figure 1 - Fungal remains from the Gray Fossil Site. a, b Cephalothecoidomyces neogenicus, isolated plates of cephalothecoid peridium. c-e Cenococcum cf. geophilum, fragments of mantle tissue with characteristic stellate-like arrangement of cells. $\mathrm{f}-\mathrm{i}$ Trichothyrites $\mathrm{cf}$. padappakarensis, f-sporocarp, g-sporocarp note upper layer of scutellum (arrow), h-sporocarp, note lower layer of scutellum (arrow), i-detail of ostiolae. Scale bars: $20 \mu \mathrm{m}$. 
Occurrence - To date fossil-species Trichothyrites padappakarensis has not been found in the Cenozoic deposits of USA. Sporocarps of fossil-genus Trichothyrites were reported from Pleistocene deposits of Springfield, Minnesota (as T. pleistocaenicus Rosendahl, Rosendahl 1943) and Pleistocene deposits of Lee County, Iowa (as Trichothyrites sp., Wilson 1952). Up to now 14 fossilspecies of Trichothyrites have been described worldwide from Cenozoic localities (Kalgutkar \& Jansonius 2000). Worobiec et al. (2013) reported remains of Microthyriales from the Gray Fossil Site, but these authors did not specify the taxonomical position of these fungi.

\section{Discussion}

Remains of sporocarps, morphologically similar to the extant cephalothecoid fungi from family Cephalothecaceae (Cephalothecoidomyces neogenicus) and epiphyllous member of Microthyriaceae vel Trichothyriaceae (Trichothyrites cf. padappakarensis) along with fragments of mantle tissue (synenchyma) of mycorrhizal fungus that are almost identical to the extant Cenococcum geophilum, were found in the Neogene deposits of the Gray Fossil Site, USA. Both Cephalothecoidomyces neogenicus and Trichothyrites cf. padappakarensis are new for the fossil mycota of North America, while the mantle tissue remains of Cenococcum in the fossil state are reported for the first time. The only fossil record of the genus Cenococcum from North America concerns its sclerotia found in Quaternary deposits, particularly from archaeological sites (e.g. Shay \& Kapinga 1997). As it was mentioned earlier, sporocarps of fossil representatives of Trichothyrites were earlier reported from Pleistocene localities of USA (Rosendahl 1943, Wilson 1952).

The presence of the fungal remains studied could be used for the reconstruction of Neogene paleoenvironment and palaeoclimate of the Gray Fossil Site. Cephalothecoidomyces neogenicus was most probably growing on decaying wood similarly as extant members of Cephalothecaceae, which are typically found as saprobes on rotten wood or on other fungi (Cannon \& Kirk 2007). Cenococcum formed mycorrhizal associations with both woody and herbaceous plants similarly as extant Cenococcum geophilum (Trappe 1962, LoBuglio 1999, Obase et al. 2016). Extant members of family Cephalothecaceae, most probably related to fossil Cephalothecoidomyces are found in temperate areas of the Northern Hemisphere (Cannon \& Kirk 2007). Trichothyrites cf. padappakarensis, epiphyllous fungus closely related to the extant members of families Microthyriaceae and Trichothyriaceae is a better climatic proxy than Cephalothecoidomyces. Modern microthyriaceous fungi show the highest abundance and taxonomic diversity in warm and humid regions of the Earth (Reynolds \& Gilbert 2005, Thaung 2006, Hofmann 2010, Hosagoudar et al. 2011, Piepenbring et al. 2011) since high precipitation and air humidity are crucial factors for their growth (Selkirk 1975, Johnson \& Sutton 2000, Limaye et al. 2007). Considering this, some researchers correlate the presence of epiphyllous, microthyriaceous fungi in a fossil state with a humid and warm, even tropical climate (Dilcher 1965, Lange 1976, Elsik 1978, Kalgutkar \& Jansonius 2000, Tripathi 2009, Conran et al. 2016). Some extant microthyriaceous fungi, however, do not require favourable thermal conditions and are found even in polar areas with wet climate (Lind 1928, Dennis 1968, Holm \& Holm 1984). On the other hand, at the Gray Fossil Site were found remains of sporodochia of fossil-genus Callimothallus Dilcher (Zobaa et al. 2011). The presence of fungal sporodochia of Callimothallus is a good proxy of climatic conditions in the past (Worobiec \& Worobiec 2017) and points to warm and humid climates in the southeast USA during the late Neogene. To sum up, on the basis of the presence of fungal remains of Callimothallus, Cephalothecoidomyces, and Trichothyrites, we can infer a warm temperate and humid climate of the period of sedimentation of deposits of the Gray Fossil Site.

The fungal remains from the Gray Fossil Sites were accompanied by moderately diversified palynoflora with a strong domination of angiosperm pollen, mainly from two genera (viz., Quercus and Carya). These trees were the main components of an oak-hickory forest, with a small admixture of other plants, such as Ulmus, Juglans, Pinus, Vitis, among others. Pollen grains of herbs (Cyperaceae, Poaceae and Asteraceae) were encountered regularly, but they were not abundant (Ochoa et al. 2012, Worobiec et al. 2013). In addition, microfossils of freshwater algae were present in all Gray Fossil Site samples. Their compositions vary among the pits, nevertheless 
in all pits peridinioid dinoflagellate cysts and resting cells of the Zygnemataceae green algae (most probably Spirogyra and Zygnema) were the most frequent. Those resting cells point to the presence of shallow sinkhole pond water, permitting easy warming and possible periodical drying up (Worobiec et al. 2013). Warmer and drier climatic conditions were previously deduced using plant fossils identified from the Gray Fossil Site, as well as from the common occurrence of charcoals all over the fossiliferous laminated layers, contributed by forest fires (Jiang \& Liu 2008, Liu \& Zavada 2009). On the other hand, the presence of epiphyllous fungal sporocarps in samples from all the pits and the palaeoclimatic reconstruction of the Gray Fossil Site fossil flora (Liu \& Zavada 2009) likely indicate a rather high mean annual precipitation (over $1000 \mathrm{~mm}$ ) in the late Neogene. It would be most probable that the higher precipitation during the wettest months made possible the development of the microthyriaceous epiphyllous fungi, whereas during the driest months the water bodies in the palaeosinkhole might have dried up and forest fires could then have occurred (Worobiec et al. 2013).

Fossil fungi are important also for the calibration of the divergence time estimations in the phylogenetic trees (e.g. Sánchez-Ramírez et al. 2017). This is especially true in case of Cephalothecoidomyces neogenicus. The presence of this fossil-species at the Gray Fossil Site is the first fossil record of cephalothecoid fungi in the area of North America. Previous results on investigation of fossil cepahlothecoid fungi revealed their presence in the fossil state in the Neogene of Europe and, on the basis of presumably remains, in Africa, Asia and South America, mostly in Neogene deposits (Worobiec et al. 2017). Thus, the fossil record of cephalothecoid fungi now covers almost all the continents (with exception of Australia and Antarctica) and confirms presence of cephalothecoid fungi at least from Neogene period. Mycorrhizal Cenococcum from the Gray Fossil Site could constitute the oldest record of this genus in the fossil state and first record of mantle tissue of Cenococcum in Neogene deposits. It provides an important premise of the presence of ectomycorrhizas in the fossil state (Sánchez-Ramírez et al. 2017) and to date back mycorrhizal associations of Cenococcum to the Neogene period.

\section{Acknowledgements}

The studies have been supported by the W. Szafer Institute of Botany, Polish Academy of Sciences, Kraków, Poland through the statutory funds and partially by U.S. NSF EAR-0746105 to Dr. Y.C. Liu. Dr. hab. Piotr Mleczko (Institute of Botany, Jagiellonian University, Poland) is acknowledged for valuable suggestions concerning mycorrhiza of Cenococcum and Tomentella.

\section{References}

Agerer R. 1999 - Mycorrhizae: Ectotrophic and Ectendotrophic Mycorrhizae. In: Esser K, Kadereit JW, Lüttge U, Runge M. (eds), Progress in Botany 60, 471-501.

Agerer R. 2006 - Fungal relationships and structural identity of their ectomycorrhizae. Mycological Progress 5(2), 67-107.

Beimforde C, Feldberg K, Nylinder S, Rikkinen J. 2014 - Estimating the Phanerozoic history of the Ascomycota lineages: combining fossil and molecular data. Molecular phylogenetics and evolution 78, 386-398.

Beimforde C, Schäfer N, Dörfelt H, Nascimbene PC et al. 2011 - Ectomycorrhizas from a Lower Eocene angiosperm forest. New Phytologist 192(4), 988-996.

Bennike O, Abrahamsen N, Bak M, Israelson C et al. 2002 - A multi-proxy study of Pliocene sediments from Île de France, North-East Greenland. Palaeogeography, Palaeoclimatology, Palaeoecology 186(1-2), 1-23.

Bird C, McCleneghan C. 2005 - Morphological and functional diversity of ectomycorrhizal fungi on Roan Mountain (NC/TN). Southeastern Naturalist 4(1), 121-132.

Boardman GS, Schubert BW. 2011 - First Mio-Pliocene salamander fossil assemblage from the southern Appalachian. Palaeontologia Electronica 14, 1-19.

Cannon PF, Kirk PM. 2007 - Fungal families of the world. CABI, Wallingford, pp. 456. 
Conran JG, Bannister JM, Reichgelt T, Lee DE. 2016 - Epiphyllous fungi and leaf physiognomy suggest an ever-wet humid mesothermal (subtropical) climate in the late Eocene of southern New Zealand. Palaeogeography, Palaeoclimatology, Palaeoecology 452, 1-10.

Czaplewski NJ. 2017 - First report of bats (Mammalia: Chiroptera) from the Gray Fossil Site (late Miocene or early Pliocene), Tennessee, USA. PeerJ 5, e3263.

Dennis RWG. 1968 - Fungi from South Georgia. Kew Bulletin 22, 445-448.

Dilcher DL. 1965 - Epiphyllous fungi from Eocene deposits in western Tennessee, USA. Palaeontographica B 116, 1-54.

Doveri F. 2011 - Addition to "Fungi Fimicoli Italici": An update on the occurrence of coprophilous Basidiomycetes and Ascomycetes in Italy with new records and descriptions. Mycosphere 2(4), 331-427.

Doveri F. 2013 - An additional update on the genus Chaetomium with descriptions of two coprophilous species, new to Italy. Mycosphere 4(4), 820-846.

Doveri F. 2014 - Coprophilous pyrenomycetes sl from the Tuscan Archipelago and adjacent peninsular coast: description of five species new to Italy. Mycosphere 5, 188-216.

Elsik WC. 1978 - Classification and geologic history of the microthyriaceous fungi. In: Proceedings of the IV International Palynological Conference, Lucknow (1976-77) 1, 331342.

Elsik WC. 1996 - Fungi. In: Jansonius J, McGregor DC. (eds), Palynology: Principles and Applications 1. AASP Foundation, Dallas, 293-305.

Fischer TC, Butzmann R. 2006 - The Pliocene macro-and microflora of lacustrine sediments from Meleto (Valdarno, N. Italy) and its ecological, palaeobiogeographical and climatic interpretation. Cainozoic Research 5(1/2), 71-83.

Gong F, Karsai I, Liu Y. 2010 - Vitis seeds (Vitaceae) from the late Neogene Gray Fossil Site, northeastern Tennessee, U.S.A. Review of Palaeobotany and Palynology 162, 71-83.

Greif MD, Tsuneda A, Currah RS. 2004 - The peridial development and dehiscence mechanism of Cryptendoxyla hypophloia, a cleistothecial ascomycete isolated from the bodies of arthropods. International Journal of Plant Sciences 165, 957-964.

Greif MD, Stchigel AM, Miller AN, Huhndorf SM. 2009 - A re-evaluation of genus Chaetomidium based on molecular and morphological characters. Mycologia 101, 554-564.

Hofmann TA. 2010 - Plant parasitic Asterinaceae and Microthyriaceae from the Neotropics (Panama). PhD thesis. The faculty of biological sciences at the JW Goethe-University Frankfurt am Main, Germany, pp. 408.

Holm K, Holm L. 1984 - A contribution to the mycoflora of Iceland. Acta Botanica Islandica 7, 311.

Hongsanan S, Hyde KD. 2017 - Phylogenetic placement of Micropeltidaceae. Mycosphere 8(10), 1930-1942.

Hongsanan S, Maharachchikumbura SS, Hyde KD, Samarakoon MC et al. 2017 - An updated phylogeny of Sordariomycetes based on phylogenetic and molecular clock evidence. Fungal Diversity 84, 25-41.

Hongsanan S, Sánchez-Ramírez S, Crous PW, Ariyawansa HA et al. 2016 - The evolution of fungal epiphytes. Mycosphere 7, 1690-1712.

Hosagoudar VB, Jagath Thimmaiah C, Jayashankara M. 2011 - Five Asteridiella species from Kodagu, Karnataka, India. Mycosphere 2, 611-615.

Huang YJ, Liu Y, Zavada M. 2014 - New fossil fruits of Carya (Juglandaceae) from the latest Miocene to earliest Pliocene in Tennessee, eastern United States. Journal of systematics and evolution 52(4), 508-520.

Huang YJ, Liu Y, Wen J, Quan C. 2015 - First fossil record of Staphylea L. (Staphyleaceae) from North America, and its biogeographic implications. Plant Systematics and Evolution 301(9), 2203-2218. 
Hulbert RC, Wallace SC, Klippel WE, Parmalee PW. 2009 - Cranial morphology and systematics of an extraordinary sample of the late Neogene dwarf tapir, Tapirus polensis (Olsen). Journal of Paleontology 83, 238-262.

Ingleby K, Mason PA, Last FT, Fleming LV. 1990 - Identification of ectomycorrhizas. ITE research publication no. 5. Institute of Terrestrial Ecology, London, HMSO, pp. 112.

Jain KP, Gupta RC. 1970 - Some fungal remains from the Tertiaries of Kerala Coast. Palaeobotanist 18(2), 177-182.

Jakucs E, Erős-Honti Z. 2008 - Morphological-anatomical characterization and identification of Tomentella ectomycorrhizas. Mycorrhiza 18(6-7), 277-285.

Jiang YL, Liu Y. 2008 - A simple and convenient determination of perylene preserved in the late Neogene wood from north eastern Tennessee using fluorescence spectroscopy. Organic Geochemistry 39, 1462-1465.

Johnson EM, Sutton TB. 2000 - Response of two fungi in the apple sooty blotch complex to temperature and relative humidity. Phytopathology, 90, 362-367.

Kalgutkar RM, Jansonius J. 2000 - Synopsis of fossil fungal spores, mycelia and fructifications. American Association of Stratigraphic Palynologist Foundation Contributions Series 39, 1429.

Kirk P, Cannon P, Stalpers J. 2008 - Dictionary of the Fungi, 10th edition. CABI, Wallingford, pp. 784.

Kołaczek P, Zubek S, Błaszkowski J, Mleczko P et al. 2013 - Erosion or plant succession - How to interpret the presence of arbuscular mycorrhizal fungi (Glomeromycota) spores in pollen profiles collected from mires. Review of Palaeobotany and Palynology 189, 29-37.

Korf RP. 1958 - Japanese Discomycete Notes I-VIII. Science Reports of the Yokohama National University, Section II. Biological and Geological Sciences 7, 7-35.

Lange RT. 1976 - Fossil epiphyllous "germlings", their living equivalents and their palaeohabitat indicator value. Neues Jahrbuch für Geologie und Paläontologie Abhandlung 151, 142-165.

Limaye RB, Kumaran KPN, Nair KM, Padmalal D. 2007 - Non-pollen palynomorphs as potential palaeoenvironmental indicators in the Late Quaternary sediments of the west coast of India. Current Science 92, 1370-1382.

Lind JVA. 1928 - The micromycetes of Svalbard. Skrifter om Svalbard og Ishavet 13, 1-61.

Liu JK, Hyde KD, Jeewon R, Phillips AJ et al. 2017 - Ranking higher taxa using divergence times: a case study in Dothideomycetes. Fungal Diversity 84, 75-99.

Liu NG, Ariyawansa HA, Hyde KD, Maharachchikumbura SSN et al. 2016 - Perspectives into the value of genera, families and orders in classification. Mycosphere 7, 1649-1668.

Liu Y, Jacques FMB. 2010 - Sinomenium macrocarpus sp. nov. (Menispermaceae) from the Miocene-Pliocene transition of Gray, northeast Tennessee, USA. Review of Palaeobotany and Palynology 159, 112-122.

Liu Y, Zavada MS. 2009 - Paleoclimate reconstruction of the late Neogene flora from Gray, Tennessee. Abstracts of Botanical Society of America Annual Meeting, July 25-29, 2009, Snowbird, Utah.

LoBuglio KF. 1999 - Cenococcum. In: Cairney JWG, Chambers SM. (eds), Ectomycorrhizal Fungi Key Genera in Profile, 287-309.

LoBuglio KF, Berbee ML, Taylor JW. 1996 - Phylogenetic Origins of the Asexual Mycorrhizal Symbiont Cenococcum geophilum Fr. and Other Mycorrhizal Fungi among the Ascomycetes. Molecular Phylogenetics and Evolution 6(2), 287-294.

Lumbsch HT, Huhndorf SM. 2010 - Myconet Volume 14. Part One. Outline of Ascomycota 2009. Part Two. Notes on Ascomycete systematics. Nos. 4751-5113. Fieldiana: Life and Earth Sciences 1, 1-64.

Maharachchikumbura SSN, Hyde KD, Jones EBG, McKenzie EHC et al. 2016. Families of Sordariomycetes. Fungal Diversity 79, 1-317. 
Mapook A, Hyde KD, Hongsanan S, Phukhamsakda C et al. 2016 - Palawaniaceae fam. nov., a new family (Dothideomycetes, Ascomycota) to accommodate Palawania species and their evolutionary time estimates. Mycosphere 7, 1732-1745.

Mead JI, Schubert BW, Wallace SC, Swift SL. 2012 - Helodermatid lizard from the Mio-Pliocene oak-hickory forest of Tennessee, eastern USA, and a review of monstersaurian osteoderms. Acta Palaeontologica Polonica 57, 111-121.

Moore PD, Webb JA, Collinson ME. 1991 - Pollen analysis. Blackwell Scientific Publications, Oxford, $216 \mathrm{pp}$.

Mudie PJ, Lelièvre MA. 2013 - Palynological study of a Mi'kmaw shell midden, Northeast Nova Scotia, Canada. Journal of Archaeological Science 40(4), 2161-2175.

Obase K, Douhan GW, Matsuda Y, Smith ME. 2016 - Revisiting phylogenetic diversity and cryptic species of Cenococcum geophilum sensu lato. Mycorrhiza 26(6), 529-540.

Ochoa D, Whitelaw M, Liu Y, Zavada M. 2012 - Palynology from Neogene sediments at the Gray Fossil Site, Tennessee, USA: Floristic Implications. Review of Palaeobotany and Palynology 184, 36-48.

Ochoa D, Zavada MS, Liu Y, Farlow JO. 2016 - Floristic implications of two contemporaneous inland upper Neogene sites in the eastern US: Pipe Creek Sinkhole, Indiana, and the Gray Fossil Site, Tennessee (USA). Palaeobiodiversity and Palaeoenvironments 96(2), 239-254.

Parmalee PW, Klippel WE, Meylan PA, Holman JA. 2002 - A late Miocene-early Pliocene population of Trachemys (Testudines: Emydidae) from east Tennessee. Annals of Carnegie Museum 71, 233-239.

Phukhamsakda C, Hongsanan S, Ryberg M, Ariyawansa HA et al. 2016 - The evolution of Massarineae with Longipedicellataceae fam. nov. Mycosphere 7, 1713-1731.

Piepenbring M, Hofmann TA, Kirschner R, Mangelsdorff R et al. 2011 - Diversity patterns of Neotropical plant parasitic microfungi. Ecotropica 17, 27-40.

Reynolds DR, Gilbert GS. 2005 - Epifoliar fungi from Queensland, Australia. Australian Systematic Botany 18, 265-289.

Rosendahl CO. 1943 - Some fossil fungi from Minnesota. Bulletin of the Torrey Botanical Club 70, 126-138.

Samarakoon MC, Hyde KD, Promputtha I, Ariyawansa HA et al. 2016a - Divergence and ranking of taxa across the kingdoms Animalia, Fungi and Plantae. Mycosphere 7, 1678-1689.

Samarakoon MC, Hyde KD, Promputtha I, Hongsanan S et al. 2016b - Evolution of Xylariomycetidae (Ascomycota: Sordariomycetes). Mycosphere 7, 1746-1761.

Samuels JX, Bredehoeft KE, Wallace SC. 2018 - A new species of Gulo from the Early Pliocene Gray Fossil Site (Eastern United States); rethinking the evolution of wolverines. PeerJ 6, e4648.

Sánchez-Ramírez S, Wilson AW, Ryberg M. 2017 - Overview of Phylogenetic Approaches to Mycorrhizal Biogeography, Diversity and Evolution. In: Tedersoo L. (ed), Biogeography of Mycorrhizal Symbiosis. Ecological Studies. Analysis and Synthesis 230, 1-37.

Schubert BW, Wallace SC. 2006 - Amphibians and reptiles of the Mio-Pliocene Gray Fossil Site and their paleoecological implications. Journal of Vertebrate Paleontology 26(3), 122A.

Selkirk DR. 1975 - Tertiary fossil fungi from Kiandra, New South Wales. Proceedings of the Linnean Society of New South Wales 97, 141-149.

Shay CT, Kapinga MR. 1997 - Cenococcum geophilum sclerotia from an archaeological site in western Canada. North American Archaeologist 18(4), 363-370.

Shunk AJ, Driese SG, Clark GM. 2006 - Latest Miocene to earliest Pliocene sedimentation and climate record derived from paleosinkhole fill deposits, Gray Fossil Site, northeast Tennessee, U.S.A. Palaeogeography, Palaeoclimatology, Palaeoecology 231, 265-278.

Thaung MM. 2006 - Biodiversity of phylloplane ascomycetes in Burma. Australasian Mycologist $25,5-23$.

Trappe JM. 1962 - Cenococcum graniforme - its distribution, ecology, mycorrhiza formation, and inherent variation. Dissertation, University of Washington, pp. 148. 
Tripathi SKM. 2009 - Fungi from Palaeoenvironments: Their Role in Environmental Interpretations. In: Misra JK, Deshmukh SK (Eds), Fungi from different environments. Progress in Mycological Research Series, 1-27.

Wallace SC, Wang X. 2004 - Two new carnivores from an unusual late Tertiary forest biota in eastern North America. Nature 431, 556-559.

Wijayawardene DNN, McKenzie EHC, Hyde KD. 2012 - Towards incorporating anamorphic fungi in a natural classification - checklist and notes for 2011. Mycosphere 3, 157-228.

Wijayawardene NN, Hyde KD, Lumbsch HT, Liu JK et al. 2018 - Outline of Ascomycota: 2017. Fungal Diversity 88, 167-263.

Wilson LR. 1952 - An aftonian plant locality in Lee County, Iowa. Proceedings of the Iowa Academy of Science 59(1), 307-321.

Worobiec E, Liu Y, Zavada MS. 2013 - Palaeoenvironment of late Neogene lacustrine sediments at the Gray Fossil Site, Tennessee, USA. Annales Societatis Geologorum Poloniae 83(1), 5163.

Worobiec G, Worobiec E. 2017 - Epiphyllous fungi from Miocene deposits of the Bełchatów Lignite Mine (Central Poland). Mycosphere 8(8), 1003-1013.

Worobiec G, Neumann FH, Worobiec E, Nitz V et al. 2017 - New fungal cephalothecoid-like fructifications from central European Neogene deposits. Fungal Biology 121(3), 285-292.

Wu HX, Schoch CL, Boonmee S, Bahkali AH et al. 2011 - A reappraisal of Microthyriaceae. Fungal Diversity 51, 189-248.

Zobaa MK, Zavada MS, Whitelaw MJ, Shunk AJ et al. 2011 - Palynology and palynofacies analyses of the Gray Fossil Site, eastern Tennessee: Their role in understanding the basin-fill history. Palaeogeography, Palaeoclimatology, Palaeoecology 308, 433-444. 